\title{
Report
}

\section{Culture of Human Gingival Fibroblasts: An Experimental Model}

\author{
Raoul Bationo ${ }^{1, ~ *, ~ A b l a s s e ́ ~ R o u a m b a ~}{ }^{2}$, Abdoulaziz Diarra ${ }^{3}$, Monique Lydie Beugré-Kouassi ${ }^{4}$, \\ Fabienne Jordana ${ }^{5}$, Jean-Bertin Beugré ${ }^{4}$ \\ ${ }^{1} \mathrm{CHU}$ de Bogodogo, Ouagadougou, Burkina Faso, Université Félix Houphouët-Boigny, Abidjan, Côte d’Ivoire \\ ${ }^{2}$ Université Joseph Ki-Zerbo/Laboratoire de Biochimie et de Chimie Appliquées, Ouagadougou, Burkina Faso \\ ${ }^{3} \mathrm{CHU}$ de Tengandogo, Université Joseph Ki-Zerbo/UFR SDS, Ouagadougou, Burkina Faso \\ ${ }^{4}$ Département d'Orthopédie Dento-Faciale/UFR d'Odonto-stomatologie, Université Félix Houphouët-Boigny, Abidjan, Côte d'Ivoire \\ ${ }^{5}$ CHU de Nantes/Service d'Odontologie, Université de Nantes/UFR d'Odontologie, Nantes, France
}

\section{Email address:}

raobat10@yahoo.fr (R. Bationo)

${ }^{*}$ Corresponding author

\section{To cite this article:}

Raoul Bationo, Ablassé Rouamba, Abdoulaziz Diarra, Monique Lydie Beugré-Kouassi, Fabienne Jordana, Jean-Bertin Beugré. Culture of Human Gingival Fibroblasts: An Experimental Model. Cell Biology. Vol. 8, No. 1, 2020, pp. 8-11. doi: 10.11648/j.cb.20200801.12

Received: May 5, 2020; Accepted: June 11, 2020; Published: June 20, 2020

\begin{abstract}
Cell culture is an important tool in medical, odontological and biological research laboratories, supporting cell therapies and tissue bioengineering strategies. It is used as a means for in vitro testing of the biocompatibility of resin polymers used in dentistry. The majority of cells are cultured with Dulbecco's modified Eagle's medium (DMEM) or RPMI supplemented with fetal bovine serum. Several cell types are being studied including gingival fibroblasts. Gingival fibroblasts are the main cells of gingival connective tissue. These cells play an active and important role in almost all coating fabric processes, and its involvement in various pathophysiological conditions, including, healing, repair, aging, psoriasis, cancer among others, is only beginning to be understood. DMEM is the most widely used fibroblastic culture medium. This model describes a method for obtaining and cultivating human gingival fibroblasts, by explants derived from surgical discards. Fibroblasts were isolated mechanically and cultured in RPMI 1640 culture medium supplemented with fetal bovine serum 10\%, Penicillin $(10000 \mathrm{U} / \mathrm{ml}) /$ Streptomycin $(10 \mathrm{mg} / \mathrm{ml}) 1 \%$ and L-Glutamine $(200 \mathrm{mM}) 1 \%$. The culture medium is replaced every two days. Cells forming a fairly dense network were observed after a period of 4 days of culture. Human gingival fibroblasts can be cultured by direct explant technique with RPMI 1640 culture medium supplemented with fetal bovine serum and antibiotics.
\end{abstract}

Keywords: Cell Culture, Gingival Fibroblast, RPMI 1640 Culture Medium

\section{Introduction}

Gingival fibroblasts are the main cells of gingival connective tissue [1]. They are involved in the repair of gingival connective tissue and in the mediation of epithelial cell morphogenesis, also aiding in the restoration of oral epithelium $[2,3]$.

Fibroblast is ubiquitous mesenchymal cell involved in many vital functions including embryogenesis and development, homeostasis and tissue repair [4-6]. Fibroblasts play an active and important role in almost all coating fabric processes, and its involvement in various pathophysiological conditions, including, healing, repair, aging, psoriasis, cancer among others, is only beginning to be understood [7].

Cell culture is an important tool in medical, odontological and biological research laboratories, supporting cell therapies and tissue bioengineering strategies. It is used as a means for in vitro testing of the biocompatibility of resin polymers used in dentistry. Dulbecco's modified Eagle's medium (DMEM) is the most used culture medium for cell culture.

The present study intends to describe a method for obtaining and cultivating human gingival fibroblasts, by explants derived from surgical discards, for in vitro research. This model was 
inspired by that of Keira et al. [8]. It will allow the assessment of the biocompatibility of resin-based materials.

\section{Method Description}

\subsection{Gingival Tissue Removal}

Surgical gum waste from dental extraction in a patient who has given his consent and has no periodontal pathology are cut into small pieces with surgical blade.

Gum specimens are placed in a tube containing RPMI 1640 culture medium (Sigma-Aldrich, St Louis, USA). The sample is stored at room temperature and then transported to the laboratory within 4 hours.

\subsection{Fibroblasts Primary Culture}

The explants are rinsed with phosphate buffered saline (PBS) (Medicago AB Sweden) and then laid onto the connective side in a $100 \mathrm{~mm}^{2}$ Petri dish. The dish is kept semi-open under laminar flow for 30 minutes so that explants can adhere to the culture surface. Culture medium is instilled on the explants to prevent them from drying out and to maintain cell viability.

$10 \mathrm{ml}$ of RPMI 1640 culture medium supplemented with fetal bovine serum 10\% (Sigma-Aldrich, St Louis, USA), Penicillin $(10000 \mathrm{U} / \mathrm{ml}) /$ Streptomycin $(10 \quad \mathrm{mg} / \mathrm{ml}) \quad 1 \%$ (Sigma-Aldrich, St Louis, USA) and L-Glutamine (200 mM) $1 \%$ (Sigma-Aldrich, St Louis, USA) is poured in the dish then it is stored in humidified incubator at $37{ }^{\circ} \mathrm{C}$ under $5 \% \mathrm{CO}_{2}$ in air. (Figure 1).

The culture medium is replaced every two days up to confluence.



Figure 1. Petri dish with gum explants in its surface into culture medium.

\subsection{Fibroblasts Subculture}

After aspiration of the culture medium, the Petri dish is rinsed with $5 \mathrm{ml}$ of PBS for 30 seconds in order to remove dead cells. PBS is aspirated and then $10 \mathrm{ml}$ of culture medium is poured to the dish.

Cells are observed under an inverted microscope (Figures 2 and 3).

When cells have reached the confluence stage, explants are removed from the dish and culture medium is aspirated. Cells are rinsed twice at PBS and then kept in humidified incubator for 20 minutes with $10 \mathrm{ml}$ of PBS.

PBS is aspirated and $1.5 \mathrm{ml}$ of trypsin + EDTA $(0,25 \%+$ $0,02 \%$ in PBS $1 \mathrm{X}$ ) is instilled in the dish for 3 minutes at $37^{\circ} \mathrm{C}$ to detach and separate the cells. Mechanical separation is also carried by multiple pipetting. $8.5 \mathrm{ml}$ of culture medium is then added to the dish to deactivate the trypsin. The whole is transferred into Falcon 15 tubes and centrifuged for 5 minutes to $0.2 \mathrm{rpm}$ (Figure 4 ).

The supernatant is aspirated without going to the bottom. 10 $\mathrm{ml}$ of culture medium is added to each tube to resuspend the cells. This suspension can be used in the context of biocompatibility tests.

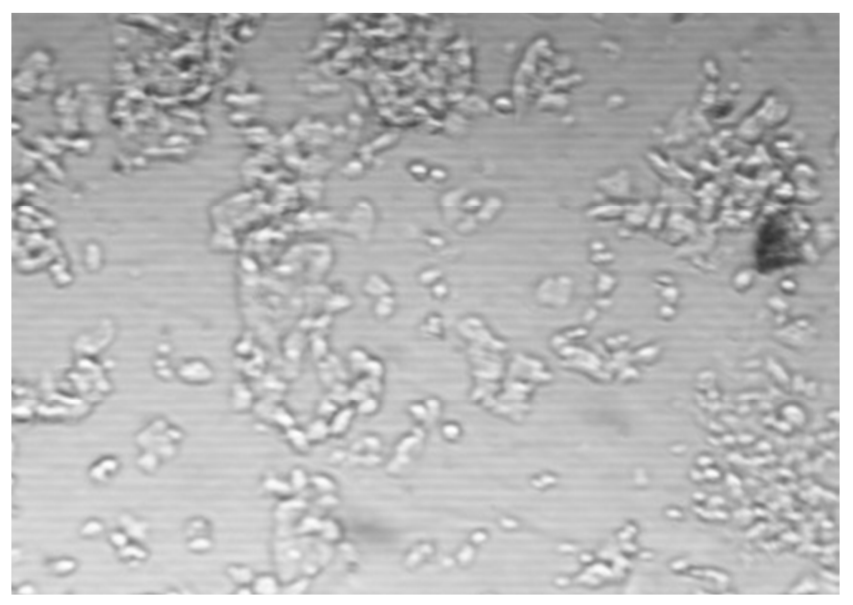

Figure 2. Gingival fibroblasts in the Petri dish after 4 days of culture (10x magnification).

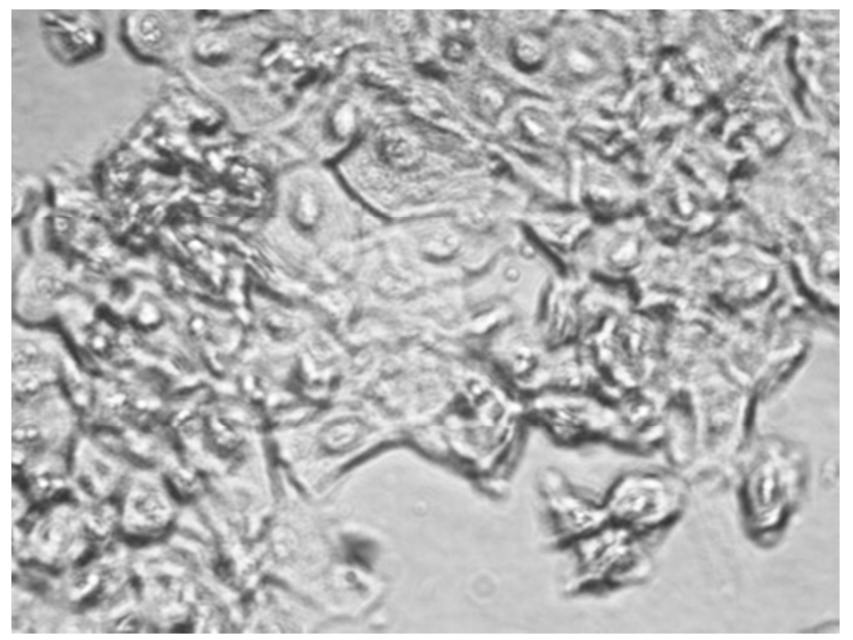

Figure 3. Gingival fibroblasts in the Petri dish after 4 days of culture (40x magnification). 


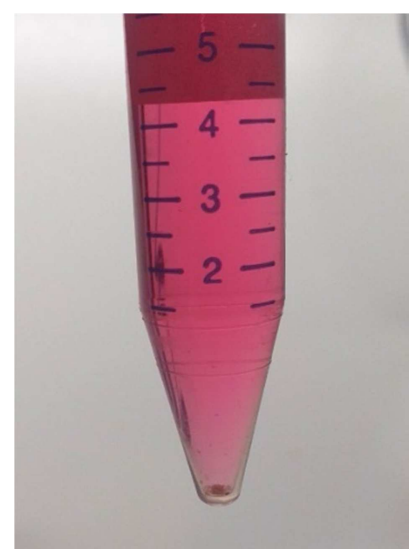

Figure 4. Cell deposition at the bottom the tube after centrifugation.

\section{Discussion}

The techniques of cell culturing are used to study the gene expression and cytotoxicity testing. Primary cell culturing of human oral tissue has many applications for oral biology research, including the study of differentiation processes, effects of drugs, and chromosomal analysis [9]. There are two techniques in primary oral tissue culture, which includes the enzymatic and direct explant technique. Two techniques that have been used to cultivate oral tissue are the enzymatic and direct explant techniques [10-12]. The direct explant technique has been used for 30 years in the culturing of human gingival [13] and buccal tissues [14].

Daniels et al. [15] described the enzymatic technique, where they surveyed the success rate of human keratinocyte isolation with various concentrations including trypsin and dispase, the enzymatic condition, as well as the calcium concentration in the culture medium. The operating procedure used in the direct explant technique process involves fewer steps compared with the enzymatic technique [12].

The culture of explant of human gingival connective tissue is a viable method for obtaining gingival connective tissue cells suitable for laboratory tests in cell culture, aiming at obtaining constructs for gingival tissue engineering [16].

The majority of cells are cultured with DMEM or RPMI supplemented with fetal bovine serum (FBS), which contains numerous factors, including cytokines, nutrients and unknown growth factors. These factors may affect cell growth, apoptosis and differentiation [17].

The present model isolated mechanically and cultured human gingival fibroblasts in RPMI 1640 supplemented with FBS $10 \%$, Penicillin $(10000 \mathrm{U} / \mathrm{ml}) /$ Streptomycin $(10 \mathrm{mg} / \mathrm{ml})$ $1 \%$ and L-Glutamine $(200 \mathrm{mM}) 1 \%$. Saczko et al. [18] cultured human gingival fibroblasts in DMEM containing FBS $10 \%$ FBS and Penicillin (100 IU/ml), Streptomycin (100 $\mu \mathrm{g} / \mathrm{ml})$ with amphotericin B $(100 \mu \mathrm{g} / \mathrm{ml})$. The use of amphotericin B is because it protects the cells against mycological infection. A study by Pini Prato [19] isolated human fibroblast enzymatically with dispase $(5 \mathrm{mg} / \mathrm{ml})$. The fibroblasts were seeded onto a three-dimensional scaffold of benzyl ester of hyaluronic acid.

$\mathrm{Xu}$ et al. [20] compared the characteristics of human gingival fibroblasts isolated by tissue explants and by enzyme digestion methods. They concluded that enzyme-digestion showed much more mesenchymal stem cell-like properties with significantly higher self-renewal capacity and adipogenic and osteogenic differentiation ability compared with tissue-explant.

\section{Conclusion}

The direct explant technique of human gingival fibroblasts culture is a viable model for obtaining gingival cells suitable for laboratory tests.

Human gingival fibroblasts can be cultured in RPMI 1640 culture medium supplemented with fetal bovine serum, Penicillin/Streptomycin and L-Glutamine.

\section{Acknowledgements}

Manipulations were carried out to the Plateforme de culture cellulaire of Laboratoire de Biochimie et de Chimie Appliquées (LABIOCA) of Université Joseph Ki-Zerbo.

\section{References}

[1] Schroeder, H. E. and Listgarten, M. A. (1997). The gingival tissues: the architecture of periodontal protection. Periodontol 2000 13: 91-120.

[2] Mussig, E., Steinberg, T., Schulz, S., Spatz, J. P., Ulmer, J., Grabe, N., Kohl, A., Komposch, G. and Tomakidi, P. (2008). Connective-tissue fibroblasts established on micropillar interfaces are pivotal for epithelial-tissue morphogenesis. Adv Funct Mater 18 (19): 2919-2929.

[3] Locke, M., Hyland, P. L., Irwin, C. R. and Mackenzie, I. C. (2008). Modulation of gingival epithelial phenotypes by interactions with regionally defined populations of fibroblasts. J. Periodontal. Res 43 (3): 279-89.

[4] Carrel, A. and Ebeling, A. H. (1921). Age and Multiplication of Fibroblasts. J Exp Med 34 (6): 599-623.

[5] Carrel, A. and Ebeling, A. H. (1921). The Multiplication of Fibroblasts in Vitro. J Exp Med 34 (4): 317-337.

[6] Carrel, A. and Ebeling, A. H. (1926). The Fundamental Properties of the Fibroblast and the Macrophage: I. The Fibroblast. J Exp Med 44 (2): 261-284.

[7] Sriram, G., Bigliardi, P. L. and Bigliardi-Qi, M. (2015). Fibroblast heterogeneity and its implications for engineering organotypic skin models in vitro. Eur J Cell Biol 94 (11): 483-512.

[8] Keira, S. M., Ferreira, L. M., Gragnani, A., Duarte, I. S. and Santos, I. A. N. (2004). Experimental model for fibroblast culture. Acta Cir Bras 19: 11-16.

[9] Reid, C. B. A., Cloos, J., Snow, G. B. and Braakhuis, B. J. M. (1997). A simple and reliable technique for culturing of human oral keratinocytes and fibroblasts. Acta Otolaryngol 117 (4): 628-633.

[10] Bernice, M. M. (1994). Tissue Culture techniques. An Introduction, Brown-Brumfield, Inc. Ann. Arbor, MI, U.S.A, pp. 116-124. 
[11] Kedjarune, U., Pongprerachok, S., Arpornmeaklong, P. and Ungkusonmongkhon, K. (2001). Culturing primary human gingival epithelial cells: comparison of two isolation techniques. Journal of Carnio-Maxillofacial Surgery 29 (4): 224-231.

[12] Klingbeil, M. F. G., Herson, M. R., Cristo, E. B., Pinto, Jr. D. S., Yosshito, D. and Mathor, M. B. (2009). Comparison of two cellular harvesting methods for primary human oral culture of keratinocytes. Cell Tissue Bank 10 (3): 197-204.

[13] Lauer, G., Otten, J. E., Von Specht, B. U. and Schilli, W. (1991). Cultured gingival epithelium. A possible suitable material for pre-prosthetic surgery. Journal of Carniomaxillofacial Surgery 19 (1): 21-26.

[14] Flaxman, B. A., Lutzner, M. A. and Van Scott, E. J. (1967). Cell maturation and tissues organization in epithelial outgrowths from skin and buccal mucosa in vitro. The Journal of Investigative Dermatology 67: 8-14.

[15] Daniels, J. T., Kearney, J. N. and Ingham, E. (1996). Human keratinocyte isolation and cell culture: a survey of current practices in the UK. Burns 22: 35-39.
[16] Abreu, F. A. M., Reis, I. D. G., Silva, G. A. B. and Jorge, E. C. (2019). Collection and culture of human connective tissue cells from gingival explant technique for oral tissue bioengineering. Int J Morphol 37 (4): 1229-1233.

[17] Tsugeno, Y., Sato, F., Muragaki, Y. and Kato, Y. (2014). Cell culture of human gingival fibroblasts, oral cancer cells and mesothelioma cells with serum-free media, STK1 and STK2. Biomedical Reports 2: 644-648.

[18] Saczko, J., Dominiak, M., Kulbacka, J., Chwilkowska, A. and Krawczykowska, H. (2008). A simple and established method of tissue culture of human gingival fibroblasts for gingival augmentation. Folia Histochem Cytobiol 46 (1): 117-119.

[19] Pini Prato, G. P., Rotundo, R., Magnani, C. and Soranzo, C. (2000). Tissue engineering technology for gingival augmentation procedures: A case report. Int $\mathrm{J}$ Periodont Restorative Dent 20: 553-559.

[20] Xu, Q., Ji, Q., Yang, J., Xu, X., Yu, X., Wang, Z. and Deng, J. (2016). Comparison of the characteristics of human gingival fibroblasts isolated by tissue explants and by enzyme digestion methods. Int J Clin Exp Med 9 (10): 19757-19763. 